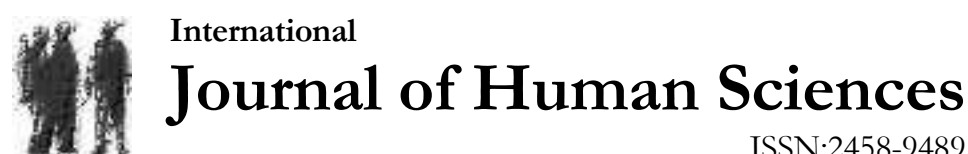

Volume: 18 Issue: 4 Year: 2021

\section{Investigation of the effect of sports on media, marketing, consumption and popular culture}

\author{
İbrahim İhsan Arkan ${ }^{1}$ \\ Summani Ekici ${ }^{2}$ \\ Varol Tutal ${ }^{3}$
}

\begin{abstract}
Reasearch problem/aim: In this study, it was aimed to evaluate them under the titles of the sports sector (media, consumption, marketing) by mentioning primarily popular culture and sports issues. Method: In this study, a descriptive research model, which is used to investigate the events as they are, trying to determine the situation that happened, investigating the events and situations discussed in detail and examining their relationship. Findings: The notion that sports is one of the building blocks of popular culture, and as a result of its action, the media sheds considerable light on consumption and marketing. The popular culture field, which started to develop as a field of study on its own, has become important by societies in the world and scientific studies on this subject have increased rapidly. Especially the innovations brought by popular culture in the world and the rapidly increasing interest in sports, media, marketing and consumer products have made this issue more up-to-date. Today, most of the sources explain that popular culture is under the influence of the media and that sports, marketing and consumption provide access to more people. Especially, social media, which enters our homes and becomes the most important part of our daily life, is extremely important in creating and conveying these topics (sports, marketing, consumption). In this context, the relationship between popular culture, media, consumption and marketing in sports and their roles among each other was discussed as a result of the extensive literature review. Conclusion: it is seen that sports have an effect on popular culture products on media, marketing and consumption.
\end{abstract}

Keywords: Sports, popular culture, media, consumption, marketing.

\footnotetext{
${ }^{1}$ Res. Assist., Ph.D., Siirt University, High School Of Physical Education And Sports, arikanibrahimihsan@gmail.com iD Orcid ID: 0000-0002-5837-9514

2 Prof. Dr., Muğla Sitk1 Koçman University, Faculty of Sport Sciences, ekicis@mu.edu.tr iD) Orcid ID: 0000-0002-9173-8021

3Ph.D., Lec., Siirt University, High School Of Physical Education And Sports, v.tutal@siirt.edu.tr (iD) Orcid ID: $\underline{0000-0001-5647-9370}$
} 
Arıkan, İ. İ., Ekici, S., \& Tutal, S. (2021). Investigation of the effect of sports on media, marketing, consumption and popular culture. Journal of Human Sciences, 18(4), 644-656. doi:10.14687/jhs.v18i4.6184

\section{Introduction}

Popular culture defines the culture in people's daily lifestyles (Oktay, 2002). It is a power that influences their lives, penetrates into their lives, and forces people who dominate daily life only and only to the consumption habits (Coşkun, 2012). In everyday life, popular culture appears in a concrete way as an expression of the economic, political and cognitive of the market in mass production. In short, popular culture is based on using and consuming (Erdoğan \& Alemdar, 2005).

There is a positive relationship between consumption and media in sports. The effect on earnings is very important for sports clubs, but the development of the media in sports has been shown to be less important than the appropriateness of an organization's financial resources (Pritchard \& Funk, 2006).

Sports marketing occurs in the system where the product within sports and sports consumers are combined. While many sports organizations are formed at the same time, some sports organizations exist alone. Professional, college or school sports need other items to create a strong sports competition. A sports competition alone may seem meaningless to people. This idea is closely related to amateur and private clubs. A sports organization with product and service support will have this meaning in itself. Sports marketing also makes its importance felt at this level (Mullin, Hardy, \& Sutton, 2000).

With the condition of active or passive participation in a sports branch, it is important for the sports industry created by sports consumption. Examining the participation in sports created by the society in popular culture and seeing the results can be economically beneficial (Erkan \& Uslu, 2019). There is a difference between physical participation in sports and passive sports consumption (Kim \& Mao, 2019). Participation in sports is fed by motives and it has been stated that the main factor is motives (Simşek, 2012). Consumption and developing technology (Xianliang \& Hongying, 2012), which are one of the basic economic activities, affect today's sports consumption behavior and the continuity of research in this direction is also extremely important (Ha, Kang, \& Kim, 2017).

From this point of view, the study tried to evaluate the media, consumption and marketing sectors, which are formed by the relationship between sports and popular culture, in the light of approaches to popular culture.

\section{Sport}

The subject of popular culture, which started to develop as a field of study on its own, became important especially in the USA and Western European societies after the 1950s, and scientific studies in this field were carried out very quickly. Studies in this field in our country have been included after the 1990s. This field, which attracts more and more attention from the fields of science, has become one of the leading fields of our time (Durmuş, 2006). Although the word sport has spread around the world with the help of English, it is not an English word. It is derived from the Latin word "Disportere" or "Deportere" which means to disperse, to separate from one another. The word used in this way was eroded over time and started to be used as "Disport". 17 years It has taken the form of "Sport" since the 19th century. Influenced by the international language interaction in our Turkish, it added the word "Sport" to its richness and started to be used as "sport" as it is pronounced (Çankaya, 2001). It needs to take sports out of a closed framework and simply take avtivities such as recreation/entertainment out of this closed frame and allow them to enter society(Şentürk,2007). Sports is one of the most common organization in society. Undoubtedly, sports is a set of events that have an important place in human life and public health in the narrowest and broadest sense (Özbaydar, 1983).

The sport, which existed for the development of humanity, was used to survive in wars and later for individual development. As the history of sports progresses and develops, individual and team sports have emerged and become an environment where people can show their desire to dominate each other (İnal, 2003). Since sport is versatile, researchers have developed different 
Arıkan, İ. İ., Ekici, S., \& Tutal, S. (2021). Investigation of the effect of sports on media, marketing, consumption and popular culture. Journal of Human Sciences, 18(4), 644-656. doi:10.14687/jhs.v18i4.6184

definitions and views. The reason for this is that the scope, branches, goals, contents and practices of sports are perceived and evaluated differently (Amman, 2000).

In modern society, the need for manpower is decreasing, and as a result, the pressures and tensions of the work and social environment, combined with the lifestyles that do not fit the natural structure of the human, circulate and cause diseases. factor. The respiratory system is one of the leading causes of death, especially in developed countries. By creating a dynamic environment away from the stress of modern life, sport brings a solution to this danger faced by modern people and helps preventive medicine with the healthy lifestyle it brings with it (Şahan, 2007). In today's industrial society, the number and variety of sports are increasing in parallel with the level of social division of labor and the development of specialization. In fact, sports have become a unique industry. Today, sports are seen as a product by many consumers. Audience in stadium, TV. Due to the large number of newspaper and magazine readers, the sports sector is preferred to promote many other products. In the current social structure, sports are used to reduce important tools in the spread of textile fashion, the important effect of sports on individuals in education, the ability of politicians to establish an active dialogue with the public and social problems. (Ozturk, 1998).

Sports is a commodity that is produced and consumed for the masses, outside of the field where the competitions are held. Although this transformation provides the change of sports and the product range next to sports, the ambiance of the stadiums has changed. The current new stadiums include a variety of products such as virtual game halls, hairdressers, cigarettes, drinks, food stands, shopping malls. The purpose of this is to ensure that the people spend time in the stadium until the evening and spend money, not the dispersal of the people at the end of the relevant match(Ritzer, 2000).

In the definition of sport, it is a kind of therapeutic drug that protects individuals in the society they live in, physically and mentally, and helps people to overcome nerves and stress in daily life(Fişek, 1980). Sport now exists far beyond this definition. Sports provides reproduction and consumption with the production logic and technique brought by leisure time.

\section{Popular Culture}

The concept of popular culture includes many meanings such as who uses it, interprets it and how it touches on which subject. Culture is generally defined as the sum of the ways people live their lives and make sense of their existence. Grazian defines popular culture as products produced and sold by organizations that appear in the global entertainment market and profit from it (Grazian, 2010). In McGaha's words, popular culture is the collection of attitudes, ideas, images, perspectives, and other formations in the mainstream of a particular culture (McGaha, 2015).

Generally speaking, popular culture is a choice of merchandise that is considered a preferred choice for many communities (Storey, 2018). It has enabled the communication between the capital created by the culture and the popular culture to be brought to light without requiring any of them to produce and consume it, by allowing its accessibility and subsequently its popularity (Parker, 2011). Most of the popular culture is seen as modern and contemporary, and the situation in which it occurs reveals the social state of the world with its birth and end, and the unique meaning of the audience allows us to think in a wide variety for the world we live in and for ourselves (Kidd, 2017). Popular culture is often linked to the so-called "convergence culture", which reflects mutual communication and interaction between producers and consumers, where social networks offer the consumer the opportunity to engage in popular culture, participate and achieve it together(Jenkins \& Deuze, 2008) and encourages social change(Brough \& Shresthova, 2011). It is this social component of popular culture that is activated through technology that makes popular culture a social phenomenon (Spracklen, 2015) because it allows people with almost the same interests to communicate. Popular culture (often abbreviated as popular culture or pop culture) is style, its mindset, ideas, and attitudes are completely different from the basic structure of culture. Since at least the beginning of the 20th century, culture has been greatly influenced by modern communication tools and has been constantly changing towards that lifestyle. Shopping for daily 
Arrkan, İ. İ., Ekici, S., \& Tutal, S. (2021). Investigation of the effect of sports on media, marketing, consumption and popular culture. Journal of Human Sciences, 18(4), 644-656. doi:10.14687/jhs.v18i4.6184

clothes, trying on shoes, gossiping and listening, watching television, consuming fast food, watching football matches, playing games, walking around the mall, etc. the rapidly growing state of popular culture in our society. Popular culture is more often referred to as pop culture; fashion, movies, music, food, etc. everything that happens in our daily life like (Wiana, 2013). People usually focus on a specific topic or person or person, and are referred to as a fan base that "has a focused interest in a particular topic, topic or person"(Thorne, 2011).

Popular culture is a concept defined differently by various people. Popular culture is a concept that is arguably conceptualized and defined based on comparison, which depends on it at a particular time. Therefore, popular culture research requires a complex mindset to understand the complexity of popular culture; What makes this rich is making it lazy. Obviously, it is a concept that is only comparatively meaningful, but what is meant to be understood is not very clear: unpopular culture is often non-descriptive (Payne \& Barbera, 2010). When describing popular culture, explanations in the basic structures of the words 'culture' and 'popular' go unnoticed, and the former has a much broader history than the latter and has been internationally recognized.

After 1950, popular culture gained more importance in the USA and Bate European civilizations and developed as a new field of study within the interiors, and then the relative scientific studies on this field were made very quickly and started to spread. In our country, studies on this field have started after the 1990s. This field, which has risen in the center of attention in the scientific community, has become one of the popular professions of our age. Sports is a repository of activities covering different branches. Some branches have been identified with various ethnic groups or shaped as belonging to a class. In the concept of popular culture; Famous stars and popular football players increased their popularity through mass media. Sports have turned into a team of individuals that include a sense of competition in the society, consisting of health, recreation, entertainment and leisure activities, and then into national feelings. In this case, the sport, which grows in this way and develops day by day, has grown in the economic field and has emerged through sponsors and advertisers who are a part of the culture(Durmuş, 2006). When the relationship between popular culture and sports is examined, it is seen that sports is a relevant field not only for the practitioner but also for the audience, which will be included in the scope of health, entertainment and leisure activities in society. It continues to be popular in the culture industry with its social, political and economic sub-dimensions (Solmaz, 2012).

Cultural anthropologists divide sport and culture into two. First, the sport is self-adjusting according to national norms; for example; They are fundamental changes made at the time, such as the game of cricket in which some primitive civilizations or communities played where they lived. Second, Sport changes some cultural values. For example; The spread of football in America through television is that it creates some important changes in the life styles of people in America(Özbaydar, 1983).

\subsection{Media as a Leverage of Postmodernism Consumption}

Consumption in postmodernism, "As social life becomes more deregulated, as social relations become more fluid and not structured by stable norms, the consumer community essentially becomes a cultural society. The overproduction of symbols and images, a steady loss of meaning and appeal to the masses through an endless stream of abstract imitations. forms." (Featherson, 1996). Owning a vehicle, which is an important component of consumption in postmodernism, is a status determinant that reflects prestige rather than meeting physical needs. Individuals believe that this consumption is more valuable in the eyes of people. Outside the realm of irreplaceable objective function, outside the realm of meaning, an object can be exchanged almost indefinitely with other objects in the realm of implications that take the sign value (Baudrillard, 1997). In the postmodern era, the image of seeing has made consumption a fictional and realistic event. The fictitious consumption is the index consumption of a product and is expressed as the peak consumption. Imaginary consumption includes fictitious consumption and there is no clear line between ad copy and actual consumption (Lefebvre, 1998). 
Arrkan, İ. İ., Ekici, S., \& Tutal, S. (2021). Investigation of the effect of sports on media, marketing, consumption and popular culture. Journal of Human Sciences, 18(4), 644-656. doi:10.14687/jhs.v18i4.6184

The media, which develops and grows with information and communication technology, fascinates people with its visibility and completely directs the mind. The most important aspect of empowering the media is the use of the internet and can be considered a cheaper and more personal activity. With this power, the media has gained the ability to transform society. This newly discovered power puts the media in a position to influence all audiences, but in the past it has had a fair political outlook, low reading habits and the average of the majority of the population (Hatipler, 2017). Thanks to this power, the media injects the value of these programs to everyone in the system of universal thought, especially with media content produced in the West. Thanks to this behavior, people's thoughts and behaviors are directed and their cognitive structures are reconstructed by repetition (Demers, 1999). The media is not innocent enough to appear to use this power. The media continues to work on assumptions, design, and who and how they affect them. The so-called reality presented by the media and the current reality do not match with each other, and even the so-called reality takes its place. This situation reveals cultural alienation in the social sense and destroys the individual's sense of belonging and trust. At this point, social collapse is inevitable (Kahraman, 2002).

\section{Popular Media}

What is the media The media system, just like the education system, is "one of the most important institutions, industries and cultural practices of the society"(Masterman, 2001). Media is mostly used in places such as communication media( radio, recorded music, internet television, print, film, video) as well as in places that feed these media (journalistic accounts, television shows and film productions, video). Central media - print media, radio and television are "one of the ways we show us our belonging more to social world(Couldry, 2003). Media is a central pedagogue, if not the first. Children, adolescents and adults use it everywhere, including places such as schools(Buckingham, 2003).

Sports and audiovisual viewing for young adults aged 16 to 34 increased from 4 hours 29 minutes to 6 hours 21 minutes in April, about two hours per day compared to the 2019 average. The influence of SVoD became even more pronounced with this. A group of teenagers who spend an average of 2 hours and 55 minutes more per day watching. Young adults spent the same amount of time watching videos and listening to music on YouTube as they spent watching live TV (including streaming and BVoD) in 2019 (Media National). 2020). YouTube time increased by 17 minutes compared to the average live TV viewing time in 2019, reaching 1 hour 25 minutes per day and 1 hour 15 minutes on live TV. Most of the time people spend on YouTube is spent on devices other than TV, with 16-34 year olds watching an average of one and a half hours of TV in April. Another notable feature of watching young adults is that they use a game console connected to the TV. This time, the average daily time was 23 minutes in 2019, almost doubling to 43 minutes in April 2020. Because game consoles are regularly connected to the internet, they may also reflect a desire to socially interact with others at a distance. Provides voice and chat communication. How to play. Others use game consoles to access different types of television content (Media National, 2020).

In addition, Sport and the media have a wide and historically close relationship. The media can increase the value of any sport in a very short time and bring it to the marketing field. Sport is a global event; everyone can reach it and establish an emotional connection with it. At the same time, this strong bond between sports and brands has been going on for many years. In the early 1890s, sports newspapers and brochures ran advertisements to provide tennis and croquet space for upper and middle class groups of people formed on the streets, and also to promote lawn and lawn mowers. Sports managers in the Victorian and Edwardian era began to form sports journalists, formerly known as sports journalists (special jargon), to introduce sports to the public and inform the public about the importance of sport for health (Vamplew, 2004). Mainly the media; It is quickly effective in the collapse of the sports wall and its applications. It has enabled the creation of competitions, organizations and leagues and their progressive development. To make the games 
Arrkan, İ. İ., Ekici, S., \& Tutal, S. (2021). Investigation of the effect of sports on media, marketing, consumption and popular culture. Journal of Human Sciences, 18(4), 644-656. doi:10.14687/jhs.v18i4.6184

fun, to spread this to the wider environment with the media and to make the audience excited as if they were in the game, and thus to evaluate the rule changes more easily(Leonard, 1988; Lewis, 2013; Sage, 2002). Even the jerseys, clothes and accessories worn by the athletes reflect the media (Houlihan, 2003). For example, night games and colorful clothing in cricket; They use tighter clothing in women's sports like netball.

In order to support sports in the field of technology, computers and TV alone are not sufficient to provide communication (Alican \& Saban, 2013). By using social media not only for communication but also for different purposes such as gaming, sports, information exchange and searching, most of the people's needs are met. Therefore, individuals who obtain what people are looking for from social media do not need different communication tools (Tektaş, 2014). In the last decade, the day-by-day rise of social media has revolutionized the sports industry in particular. One of the strongest uses of social media is the ability of people from every country around the world to communicate with each other quickly and effectively. In this context, social media platforms offer new and effective activities in the field of sports industry and new products that attract people. Teams and players can communicate with their audience who show an interest in them. Social media has also transformed sports consumption culture by moving from an individual activity to a group or community building activity. Twitter has grown itself in the sports industry worldwide and has become a resource in the form of gold: leagues, teams, players, fans, and sports reporters. Twitter provides fast and efficient access to sports news. It has become common practice for team accounts to post real-time game updates on Twitter. With the inclusion of hashtags, gifs, and audiovisual content, information and entertainment become the same. Through social media, the sports industry has entered people's daily routine.

Most of us make sense of communication by analyzing it ourselves. Deliberately or unintentionally, different examples of the media are structured to lead us to the conclusion that we must basically understand. It can be said that different communications are maintained in physical or social unity. This coexistence can be defined as a fundamental factor that always affects how communication is perceived and primarily structured(Burton, 1995). Fluctuations in the social, political or economic areas of life, while being affected by the changes in the field of communication, on the other hand, may lead to the emergence of other developments(Işık, 2007).

While the media takes a crucial responsibility for the creation of popular cultural products, popular cultural products strive to reach much larger community groups. Therefore, the media is the primary factor in the propagation of popular culture. The media plays an important role in entertainment and curiosity, which constitute the main steps of popular culture products. It has many entertainment tools of the popular media these days. The news about public events is only a small part of the media content(Curran, 1997).

Popular culture and mass communication are used today as an inseparable concept. The industrialized is produced and distributed by an industry after its economic interests. The culture industry constantly uses popular cultures in the replication process. They undergo these processes through radio and television programs, TV series, news, magazines, comics, records, cinema, and advertisements(Erdoğan, 2004).

In addition to conveying the popularity produced, mass media are also included in the popular production process. In general, popular culture elements based on the provocation of consumption desires try to feed this situation in the fastest way. Establishing attempts to constantly consume new needs of consumers and to add new needs to the wealth of producers are defined as follows: "The relationship with the production and distribution of goods is based on the creation and deprivation of wealth by overtaking private property. The relationship with the consumption of goods is to create the conditions for reproduction by using the "Marketing and Consumption of the Product". Based solely on consumption, "a culture or folk culture that is given or not given to the public is a culture that expresses themselves and defines their experiences"(Gültekin, 2006). In order to increase consumers, prepare and communicate 
Arrkan, İ. İ., Ekici, S., \& Tutal, S. (2021). Investigation of the effect of sports on media, marketing, consumption and popular culture. Journal of Human Sciences, 18(4), 644-656. doi:10.14687/jhs.v18i4.6184

consumers for purchase, producers have declared to the public their culture and popular culture products, which are the popular culture and cultural products they create. Thus, they argue, saying that people meet their wishes and expectations. It is that popular culture produces large community segments of the dominant culture(Sakalli, 2014). In addition to Alternative Orientations, the dominant structure that produces popular culture does not need the means of advertising through the culture industry. It is possible to see popular culture at every stage of life. Because popular culture is the spread of means. NDA, television, cinema, sports, literature, computer and internet titles come first among these tools(Erdal \& Dağtaş, 2009).

\subsection{Popular Culture and Social Media Relationship}

Today, perhaps the most common concept of culture is the media. This relationship continues that the media provide new lives and create and sustain images of the world. The new symbols produced by the Medians direct people's lives and create some lifestyle and create a modern cultural culture as a new time period that contains their ideas, actions and structures. In this context, the culture of the media is actually the same reflection of the popular culture as the daily culture. Engaging in popular culture "loved by the people", the media are closely related to this "loved" effect; Their daily lives, which change people's lives, perceptions, love, and their hate, shape their political-social thoughts according to their power. Therefore, it is natural for the media to be mentioned in popular culture(Geçer, 2013).

\section{Sport and Marketing}

Sport is becoming a rapidly growing world lately. It gives people happiness and pleasure in their free time. Therefore, the level of health of people is also increased. For this reason, the level of participation in sports is high today. In addition, sports discipline people and provide high willpower. Sports bring people together for a short time. For marketers, sport is something that simultaneously holds enormous customer potential. When sports come together with technology, it has become an important employment area in the world. With the help of the Internet, many sports branches are gaining popularity. Sports marketers reach their fans with the ever-changing technology and reveal various innovations for them. Later, smartphones and the Internet entered into our daily lives and became an important phenomenon. Most things can now be done with smartphones. The transition from traditional to e-commerce is a common trend today. Even sports have become easier, with popular internet and online resources without going to gyms. Instead, you can download an app for a fee or go to a website or Instagram page, communicate with people or have personal tutorials with video, chat with a nutritionist and many other benefits. This subject can be examined in terms of the increase and development of the popularity of sports. People think too much about having a healthy body. However, few can find free time and resources to go to the gym to train with private gym coaches, or to get advice on a definitive diet or how to eat to stay healthy. This may be a little too much in economic terms. Instead, a mobile application is much cheaper and more convenient to use. In advertising campaigns to be created for the purpose of promoting sports, a joint work between sports scientists and the advertising company, a clear emphasis on the message to be given to the public and more frequent coverage of interesting sports content programs will increase the interest(Ünal, 2011).

There are many articles and books on this topic. For example, for a statement on the phenomenon of sports marketing, the author, "Sports Marketing; Understanding the structure and basic principles of sports marketing is "Creating Long-Term Value" by(Davis \& Hilbert, 2013).

Significant financial trades in the sports industry, people's ever-changing living standards and leisure times, the vast balance of financial trade, and ever-increasing national, regional, continental and global sports activities are not interrupted (Hickman, Lawrence, \& Ward, 2005). When a person is looking for original and new opportunities with not too many resources, a new approach or an opportunity should be created against the unknowns in the environment (Becherer, Haynes, \& Helms, 2008). Along with the close interest in sports, the expansion of the marketing field has 
Arıkan, İ. İ., Ekici, S., \& Tutal, S. (2021). Investigation of the effect of sports on media, marketing, consumption and popular culture. Journal of Human Sciences, 18(4), 644-656. doi:10.14687/jhs.v18i4.6184

increased the interest in sports more and continues rapidly. Sports marketing science is gaining attention from institutions and organizations. Extremely important, new knowledge is used by sports marketers to predict consumer decisions (Lemon, White, \& Winer, 2002).

Marketing is created by competition. Considering today's firm, product and service statistics, it is seen that it is spreading rapidly to each sector. The result of this reveals that companies need to create new strategies and think differently in order to gain advantage. It is not possible to gain from the competition when you do not show your difference. If you want to make a difference, it is a priority to make a difference in product and communication methods and strategies. Making difference in both product and communication strategies requires priority for difference. While traditional marketing is evaluated as product, price, distribution, place and promotion, marketing communication and product communication, price communication, distribution communication and communication tools consisting of advertising, public relations, promotion and one-to-one sales With the marketing communication system has become more popular. Good quality of the product is the primary requirement of this integration. The motto "Good advertisement of a bad product ruins that product" explains this. With marketing communication, evaluating the product itself, brand, package, price and distribution within marketing is the most crucial point of marketing communication. Messages and emotions are reflected to the consumer with the shape of the product(Odabaş1 \& Oyman, 2005). The price contains information beyond the value to be paid for the product. Often shown as an indicator of product quality. Price communication reflects different meanings to people in different circumstances. The price plays an important role in symbolically reflecting the features, quality and product of the product. Distribution, the personalities of the places where the product is offered to the consumer are also a communication element. Two stores selling the same or similar products may have a different image to the consumer. Communication is the process of conveying the message and its promises to the target buyers through advertising, public relations, one-to-one sales and promotion of the product and its features. The effect of advertising the product on television, radio, newspapers, magazines, cinemas, outdoors, conducting any public relations campaign, applying the promotional strategy and selling it in purchasing centers may be different. While this definition and process covers every product and service, some of them highlight themselves. It facilitates the marketing and product communication process of sports by knowing the marketing components for sports marketing as product, place, price, promotion and public relations(Robinson, 2007). When these components are considered in the sense of sports, the product of sports is abstract, subjective, experimental, easily perishable, unstable, simultaneously produced and consumed, based on socialization, inconsistent and unpredictable, its consumer is an expert, its demand fluctuates, every segment of the society can be reached and identification is type of product (Robinson, 2007, Argan \& Katırc1, 2002).

Specifically, market orientation is now a business factor. In fact, the relationship between marketing and entrepreneurship behind growth and development is quite large; both are an important element among companies(Jones \& Rowley, 2011). Despite a number of rapidly changing things, clubs and organizations rapidly increase their entrepreneurial skills in order to increase their sustainability(Kuratko, Ireland, Covin, \& Hornsby, 2005). Research shows that companies need to benefit from entrepreneurs in order to get rid of their uncertainties in the market (Kilenthong, Hills, Hultman, \& Sclove, 2010) It facilitates both the product and sports marketing communication process by emphasizing the five elements of sports marketing (product, place, price, promotion and public relations) (Robinson, 2007). From the sports point of view, sports products are intangible, subjective, experimental, perishable, perishable, produced and consumed simultaneously based on socialization, inconsistent and unpredictable, consumers are specialized. (Robinson, 2007; Katırc1, 2002). For example, the real rivalry between the two football teams cannot be touched, but there are stadiums, hats, t-shirts, videos, etc. related to the sports experience. assets can be touched. Impressions, experiences and comments about the sports organization and the competition differ from person to person. Injury of players, 
Arrkan, İ. İ., Ekici, S., \& Tutal, S. (2021). Investigation of the effect of sports on media, marketing, consumption and popular culture. Journal of Human Sciences, 18(4), 644-656. doi:10.14687/jhs.v18i4.6184

motivation of players, team speed and weather conditions are variable. As team performance deteriorates or weakens, sports marketers often provide physical supplies (such as jerseys, souvenirs, merchandise, etc.). Some viewers have an emotional attachment to your team or may even be a fan. Logos, uniforms, etc. for you to introduce yourself as a team. They buy licensed products (Zanger, Janet, \& Jerome, 2003). Product features vary according to the abundance of sports, where they run, what equipment they need, where and when they get it in the media. The price you pay to watch a match, attend a sporting event, or buy a sporting product is the price of sports marketing. The price paid by the team to the player shows the price of the ticket, and the price of the basketball match ticket shows the price of the sports product. Distribution (location) is the way sports products reach the end consumer. The place where the products are sold and the sports competitions are held is called the sports marketing place (Argan \& Katırc1. 2002). Promotion and public relations, which are one of the communication tools of marketing communication, are an important element of sports marketing. Promotion has a huge impact on sports marketing. Promotions make your audience feel like you're part of a team and help them outperform other team supporters and identify them with successful teams and athletes. With this recognition, Turkish sports clubs focused on product sales. The power of the promotion is even greater for clubs with a large following. Another element of sports marketing is public relations. The reason why public relations stands out in sports marketing is that developments that are not in any product or service are characterized by media news. At every opportunity, such as the player who bought the team, the organization he created, the meetings the players attend, announcing what they're playing, and more. It could be media news. Therefore, planning and doing this for public relations will increase the efficiency of your team, athlete or organization (Lee, 2000).

\section{Sport Consumption}

Human nedds consumption in order to exist in life. Especially in social sciences, sonsumption has been expressed with classical economics or Marxist economics approaches until now.Anthropologists, on the other hand, acknowledge that different needs are based on material foundations, but they think that the most important issue for objects has an important factor in the formation of social personality and identity, which makes certain relationships easier(Yel, 1999).

When it comes to consumption, the first thing that comes to mind is a material phenomenon. Of course, consumption does not include material meaning; Apart from the material phenomenon, it is the state of being converted into consumption by making substances in their social, cultural and spiritual values. In short, consumption is to destroy something. Consumption is one of the most important and major problems of today's society in concrete terms, giving money and getting what we want in return.

The consumer can be called the responsible of consumption in a broad sense. In a broad sense, the consumer is the person who buys or has the capacity to purchase marketing components for personal wants, desires and needs(Coşgun, 2012).

\section{Display Consumption}

According to today's consumption perspective, more like the image, shape and brand of a product comes to the fore rather than the functionality of a product.

Image; It is based on the entire basic image of popular culture; It doesn't matter who you are, what you say, who or what it represents. Image takes precedence over many things, such as attitudes and behaviors. Especially the media, such as mass media, is to create images that become stars in economy, politics, sports and arts(Erdoğan, 2004).

Brand Preference; The goods put on the market by the popular culture industry do not have much of a meaningful value in terms of quality and quality. He wants to be concerned with the quality of a product, whether it will reach a very large audience, whether it will reach the market expansion to the environments, and therefore whether it will be adopted by the consumer mass and whether it will make a profit as a result of all commercial activities. Especially the young 
Arrkan, İ. İ., Ekici, S., \& Tutal, S. (2021). Investigation of the effect of sports on media, marketing, consumption and popular culture. Journal of Human Sciences, 18(4), 644-656. doi:10.14687/jhs.v18i4.6184

generation has the feature of being popular around the environment with brand products(Eşitgin, 2012).

Fashion: Pop culture uses fashion and prepares some products under the fashion heading, while leaving some products out. Everything has its own fashion and time(Cosgun, 2012).

The development of sports with its birth has had a large audience. With the increasing interest, sports marketing has played an important role in motivation in terms of needs, as consumption has increased. With the diversity and development of today's technologies, the consumption factor (spectators, sports fans, associations, clubs, foundations ... etc.) is a universal world of sports and its service to this world also affects people. Active or passive participation in a sports branch, the economic value for the sports industry is very important for people and society. Why do people participate in sports? Investigating the question and learning the results accordingly will give us information about how the economic dimension will be(Erkan \& Uslu, 2019). Although physical and passive participation in sports is provided, sports consumption practices are different from each other(Kim \& Mao, 2019). Nowadays, it affects sports consumption behavior in almost every dimension, especially with consumption(Xianliang \& Hongying, 2012), which has high economic power within us and the technology that is developing day by day, and its continuity is very important(Ha, Kang \& Kim, 2017).

\section{a.Sporting Goods Consumption}

Those who are directly within the sport (whether or not taken to participate in sports activities), balls, nets, jerseys, mascots, scarves, etc. The sale or purchase of such products within the scope of service includes consumption. Now, the logos of bank cards on the jerseys of almost all teams, credit cards with logos on them, some of the sports products offered by a sneaker and a tennis racket in various virtual games are very important factors in the formation of sports consumption.

\section{b.Sports Media Consumption}

Sports organizations in the media; Being unable to find time due to work, to follow up due to economic difficulties, transportation and surrounding factors brings to one's feet where and how the encounter is. They can watch the repetition of the competition or events they missed and provide detailed comments (Erdoğan, 2012). When viewers want, not only on television and radio programs, but also on the internet, consumers can access the goods or services they want 24 hours a day, 7 days a week, regardless of time and place. Especially on social media, the power of sports in popular culture is increasing and it can be made easier to communicate with others.

\section{c.Sports Events Consumption}

Professional-amateur people who do sports or spend their leisure time are considered as sports participants (Argan \& Katırc1, 2015). Coaches, managers, statisticians, followers etc. currently involved in the sports event. It is the subject of activity consumption. So sports; In addition to being a professional or amateur activity area, it is a product of recreational activities where leisure time is spent.

\section{Method}

In this study, the literature was scanned in a long period of 6 months, and the "Scanning Model", one of the qualitative research methods, was used. This model includes the researches made on the sources and publications as a result of the literature review that conducted the research. Each study has a subject and background. The researcher will be made to examine them. Every researcher or person uses this method. When the literature review in the study is examined; 21 books in English and Turkish with the keywords "sports", "popular culture", "media", "marketing" and "consumption" in Mugla Sitk1 Kocman University Library, Google Scholar, and Libgen databases between September 2020 and February 2021. , 28 journals and 56 articles, a total of 105 references were scanned. 
Arrkan, İ. İ., Ekici, S., \& Tutal, S. (2021). Investigation of the effect of sports on media, marketing, consumption and popular culture. Journal of Human Sciences, 18(4), 644-656. doi:10.14687/jhs.v18i4.6184

\section{Result and Discussion}

The rapid change and development of popular culture in the light of science characterize the development of social media and media sports as well as its continuity. Despite many trial and error processes, the role of sport in social media and media has been of great benefit in both historical and popular culture. While broadcast media in particular contributed significantly to the increase and development of sports activities in the national and international arena, the participation of companies in the field of employment and market and the increase in consumption and democratic access of people in this process provided great income. However, the beginning of the digital age is that it has entered an age based on technology and media privilege rather than universal access.

The intertwining of popular culture, media, marketing, consumption and sports in the national and international arena should be aware that governments are trying to benefit themselves politically and socially and this process will continue rapidly.

It is difficult to predict future developments in the sports industries, along with technology, marketing, consumption and media, both in media and popular culture. We can say with certainty that the emergence of the Corona virus (2019), a pandemic disease that has appeared recently, is a source that cannot be predicted by social media, especially a very large marketing tool. As a result, it is seen that sports have an effect on popular culture products on media, marketing and consumption.

\section{References}

Alican, C., \& Saban, A. (2013). Ortaokul ve lisede öğrenim gören öğrencilerin sosyal medya kullanımına ilişkin tutumları: Ürg̈̈p örneği. Sosyal Bilimler Enstitïsü Dergisi, 35(2), 1-14.

Amman, M. T. (2000). Spor Sosyolojisi. (Ed.: IKKIZLLER C.) Sporda Sosyal Bilimler, Bölïm 3, Alfa Yayznlar, İstanbul.

Argan, M. \& Katırc1, H. (2002). Spor Pazarlaması, Nobel Yayınevi. Ankara.

Argan, M. ve Katırıc1, H. (2002). Spor Pazarlaması, Nobel Yayınevi. Ankara.

Argan, M., \& Katırc1, H. (2015). Spor Pazarlamasi, Nobel Yaym, Ankara.

Baudrillard, J. (1997). Tüketim Toplumu (Çeviri: Hazal Deliceçaylı ve Ferda Keskin), İstanbul.

Becherer, R. C., Haynes, P. J., Helms, M. M. (2008). An Exploratory Investigation of Entrepreneurial Marketing in Smes: The Influence of the Owner/operator. Journal of Business and Entrepreneurship, 20(2), 44-63.

Brough, M. M., \& Shresthova, S. (2011). "Fandom meets activism: rethinking civic and political participation", Transformative Works and Cultures, Vol. 10, pp. 1-27.

Buckingham, D. (2003). Media education and the end of the critical consumer. Harvard Educational Review, 73(3), 309327.

Burton, G. (1995). Görünenden Fazlasi; Medya Analizlerine Giriş. (Çev. Nefin Dinç), İstanbul: Alan Yayıncilik.

Coşkun, M. (2012). Popüler Kültür ve Tüketim Toplumu. Batman Journal of Life Science, 1,1.

Couldry, N. (2003). Media rituals: A critical approach. London, UK: Routledge.

Curran, J. (1997). Medya ve Demokrasi, 139-197. In: Medya, Kültür, Siyaset, (Eds: Süleyman Irvan), Ark Yayinlar, Ankara.

Çankaya, C. (2001). Spor Tesisleri İşletmeciliği ve planlamacılık Ders Notları, Bursa,

Davis, J. A., \& Hilbert, J. Z. (2013). Sports marketing: Creating Long Term Value. Edward Elgar Publishing Limited.

Demers, D. (1999). Global Media Menace or Mesiah, New Jersey: Hampton Press Inc

Durmuş, O. (2006). Popüler Kültürün Kimlik Oluşumuna Etkileri: Özgür Kız Nil Karaibrahimgil Modeli. Muğla Üniversitesi Sosyal Bilimler Enstitïsü Dergisi, 17, 121-133.

Erdal, D. \& Dağtaş, B. (2009). "Tüketim Kültürü, Yaşam Tarzları, Boş Zamanlar ve Medya Üzerine Bir Literatür Taraması", Medya, Tüketim Kültürü ve Yaşam Tarzları, (Derleyenler)Banu Dağtaş, Erdal Dağtaş, Ütopya Yayınevi, Ankara s. 27-75.

Erdoğan, İ. (2004). "Popüler Kültürün Ne Olduğu Üzerine", Bilim ve Akln Aydmliğgnda Eğitim Dergisi, Say1 57 s. 1-18. 
Arıkan, İ. İ., Ekici, S., \& Tutal, S. (2021). Investigation of the effect of sports on media, marketing, consumption and popular culture. Journal of Human Sciences, 18(4), 644-656. doi:10.14687/jhs.v18i4.6184

Erdoğan, İ. ve Alemdar, K. (2005). Popüler Kültür ve İletişim. Ankara: Erk Yayınları.

Erdoğan, M. (2012). Kitlesel Spor Faaliyetleri Özelinde Spor Pazarlaması; Bjk Örneği. Bahçeşehir Üniversitesi Yüksek Lisans Tezi, 2012.

Erkan, M., \& Uslu, N. C.. (2019). Determining the scope of sports participation sports industry profile (Turkey Example). GSI Journals Serie A: Advancements in Tourism Recreation and Sports Sciences, Fashıon. Universitas Pendidikan Indonesia, 1(2) 40-53.

Eşitgin, D. (2012). Popüler Kültür Aralığında Edebiyata Bakmak. Bilim ve Akln Aydnnluğnda Eğitim Dergisi, 57, 87-91.

Featherstone, M. (1996). Postmodernizm ve Tüketim Kültürü (Çeviri: Mehmet Küçük), İstanbul.

Fişek, K. (1980). Spor Yönetimi. Ankara: BYYO.

Fişek. K. (1998) 100 Soruda Türkiye Spor Tarihi, Gerçek Yayınevi İstanbul;

Geçer, E. (2013). Medya ve Popüler Kültür. Diziler, Televizyon ve Toplum. İstanbul: Metemorfoz Yayinc1lik.

Grazian, D. (2010). Mix it Up: Mass Media, Popular Cutura and Society. New York: W.W. Norton \& Company.

Gültekin, M. (2006). "Bir Popüler Kültür Araştırmasi: Dicle Üniversitesi Örneği”, Ekev Akademi Dergisi, Say1 26 s. 115-128.

Ha, J. P., Kang, S., J., Kim, Y. (2017). Sport fans in a "smart sport" (SS) age: Drivers of smartphone use for sport consumption. International Journal of Sports Marketing and Sponsorship, 18(3), 281-297.

Hatipler, M. (2017). Postmodernizm, Tüketim, Popüler Kültür ve Medya. Bilgi Sosyal Bilimler Dergisi. 1,32-50.

Hickman, T. M., Lawrence, K. E., Ward, J. C. (2005). A social identities perspective on the effects of corporate sport sponsorship on employees. Sport Marketing Quarterly, 14(3), 148-157.

Houlihan, B. (2003). Sport and Society: A Student Introduction. London: SAGE.

Işı1k, M. (2007). Dünya ve Türkiye Bağlamında Kitle İletişim Sistemleri. Konya: Eğitim Kitabevi Yayınlar1

İnal, A. (2003). Beden Eğitimi ve Spor Bilimi, Nobel Yayın Dağıım, Ankara.

Jenkins, H., \& Deuze, M. (2008), "Editorial convergence culture", Convergence: The International Journal of Research into New Media Technologies, Vol. 14 No. 1, 5-12.

Jones, R., \& Rowley, J. (2011). Entrepreneurial marketing in small businesses: A conceptual exploration. International Small Business Journal, 29(1), 25-36.

Kidd, D. (2017). Pop Culture Freaks: Identity, Mass Media, and Society, Routledge, London.

Kilenthong, P., Hills, G. E., Hultman, C., Sclove, S. L. (2010). Entrepreneurial marketing practice: systematic relationships with firm age, firm size, and operator's status. Strategic entrepreneurship: the promise for future entrepreneurship, family business and SME research?: Rencontres de St-Gall 2010, 1-15.

Kim, M. J., \& Mao, L. L. (2019). Sport consumers motivation for live attendance and mediated sports consumption: A qualitative analysis. Sport in Society, 1-19.

Kline, S. (1993). Out of the garden: Toys, TV and children's culture in the age of marketing. London, UK: Verso.

Kuratko, D. F., Ireland, R. D., Covin, J. G., Hornsby, J. S. (2005). A Model of Middle-Level Managers' Entrepreneurial Behavior. Entrepreneurship theory and practice, 29(6), 699-716.

Lee, J. H. (2000). Sport Marketing Strategies Through The Analysis Of Sport Consumer Behaviour And Factors Influencing Attendance, A Thesis Submitted To The Faculty Of The Graduate School Of The University Of Minnesota, In Partial Fulfillment Of The Requirements For The Degree Of Doctor Of Philosophy, March.

Lefebvre, H. (1998), Modern Dünyada Gündelik Hayat, İstanbul: Metis.

Lemon, K. N., White, T. B., Winer, R. S. (2002). Dynamic customer relationship management: Incorporating future considerations into the service retention decision. Journal of marketing, 66(1), $1-14$.

Leonard, W. M. (1988). A Sociological Perspective of Sport. New York: Macmillan Publishing Company.

Lewis, J. (2013). How the Development of Media Has Influenced Football. Retrieved September 20, 2018, from: https://prezi.com/lyp_7yvezmxr/how-the-media-has-influenced-football/ McPherson, 
Arrkan, İ. İ., Ekici, S., \& Tutal, S. (2021). Investigation of the effect of sports on media, marketing, consumption and popular culture. Journal of Human Sciences, 18(4), 644-656. doi:10.14687/jhs.v18i4.6184

Masterman, L. (2001). A rationale for media education. In R. W. Kubey (Ed.), Media literacy in the information age: Current perspectives New Brunswick, NJ: Transaction Publishers, 15-68.

McGaha, J. (2015). Popular Culture \& Globalisation. Multicultural Education. Ottawa: The Author, 23(1): 32-37.

Media National, (2020). Ofcom Making Communications Work For Everyone.

Mullin B.J., Hardy, S., Sutton, W.A. (2000). Sport Marketing, Second Edition, USA: Human Kinetics, 2000.

Odabaşı, Y. \& Oyman, M. (2005). Paz̧arlama İletişimi Yönetimi, Mediacat Yayınları, İstanbul.

Oktay, A. (2002). Popüller Kültürler. İstanbul: İletişim Yayınları.

Özbaydar, S. (1983). İnsan Davranışının Sinırları ve Spor Psikolojisi. Altın Kitaplar Yaymevi.

Parker, H. N. (2011), "Toward a definition of popular culture", History and Theory, Vol. 50 No. 2, 147-70.

Payne, M., \& Barbera, J. (2010). A dictionary of cultural and critical theory. (2nd Ed.). United Kingdom: Wiley-Blackwell.

Pritchard, M.P. \& Funk, D.C. (2006), "Symbiosis and substitution in spectator sport", Journal of Sport Management, Vol. 20 No. 3, 299-321.

Ritzer, G. (2000). Büyüsü Bozulmuş Dünyayz Büyülemek. çev. Ç. S. Kaya. İstanbul: Ayrıntı.

Robinson, M. (2007) Pazarlama Departmanı Oluşturmak ve Etkili Pazarlama Planı Geliştirmek, Türkiye Basketbol Federasyonu Ligler Direktörlügüu, Basketbolda Etkin Pazarlama Semineri, Delaware Üniversitesi Spor Yönetimi Fakültesi Öğretim Üyesi,

Robinson, M. (2007). Pazarlama Departmanı Oluşturmak ve Etkili Pazarlama Planı Geliştirmek, Türkiye Basketbol Federasyonu Ligler Direktörlüğü, Basketbolda Etkin Pazarlama Semineri.

Sage, G. (2002). Global sport and global mass media. In A. Laker (Ed.), The Sociology of Sport and Physical Education: An Introductory Reader London and New York: RoutledgeFalmer, 211231.

Sakallı, E. (2014). “Türkçe Popüler Kültür”, Uluslararası Türkģe Edebiyat Kültür Eğitim Dergisi, Sayı 3/2, s. 307-317.

Simşek, K. Y. (2012). Sport consumption factors of Turkish extreme sportsmen. Ege Academic View Magazine, 12(SI), 71-84.

Solmaz, B. \& Oğuz A, (2012). Popüler Kültür ve Spor Merkezlerine Yönelik Bir Araştırma. Gümüsshane Üniversitesi Illetisim Fakïltesi E -Dergisi, 1(4), 67-82.

Spracklen, K. (2015), Digital Leisure, the Internet and Popular Culture: Communities and Identities in a Digital Age, Palgrave Macmillan, Basingstoke.

Storey, J. (2018), Cultural Theory and Popular Culture: An Introduction, Routledge, London.

Şentürk, Ü. (2007). Popüler Bir Kültür Örneği Olarak Futbol. Cumburiyet Üniversitesi Sosyal Bilimler Dergisi, 31.

Tektaş, N. (2014). Üniversite öğrencilerinin sosyal ağları kullanımlarına yönelik bir araştırma. Journal of History School, 17, 851-870.

Thorne, S. (2011). "An exploratory investigation of the theorized levels of consumer fanaticism", Qualitative Market Research: An International Journal, Vol. 14 No. 2, pp. 160-73.

Ünal, H. (2014). Spor Bilincinin Yaygınlaştırılmasında Sosyal Pazarlamanın Toplum Tutumuna Etkisi. CBÜ Beden Eğitimi ve Spor Bilimleri Dergisi:6(2)

Vamplew, W. (2004). Pay Up and Play the Game: Professional Sport in Britain, 1875-1914. Cambridge: Cambridge University Press.

Wiana, W. (2013). Popular Culture And This Phenomenon In The Culture Of Dressed.

Xianliang, L., \& Hongying, Y. (2012). The quantitative analysis on the individual characteristics of urban residents and their sport consumption motivation. Physics Procedia, 33, 2055-2063.Available at: https://doi.org/10.1016/i.phpro.2012.05.323.

Yel, A. (1999). Popüler Kültür ve Ülkemizdeki Empoze Kültür, Köprü Üç Ayllk Fikir Dergisi, 67.

Zanger, R. K., Janet, B. P., Jerome, Q. (2003). Contemporary Sport Management, Second Edition, Editors: Beverly, Published Human Kinetics. 